Beiträge zur Neotropischen Fauna

Herausgegeben von Prof. Dr. Erich Titschack und Dr. Hans-Wilhelm Koepcke. 1 Band, Heft 3 : Zur Kenntnis der Pseudoscorpioniden-Fauna des Andengebietes. Von Max Beier. Pp. 185-228. Kritische Untersuchungen der Newportia-Arten. Von Wolfgang Bücherl. Pp. 229-242. Ein neuer Asthenes (Aves, Furnariidae) von der Küste und dem westlichen Andenabhang Südperus. Von Maria Koepcke. Pp. 243-248. Beiträge zur Kenntnis der Fische Perus II. Von Hans-Wilhelm Koepcke. Pp. 249268. (Jena: Gustav Fischer Verlag, 1959.) 10.95 D.M.

$\mathrm{T}$ HE first two papers in the above collection which continues this important new publication are of considerable interest to students of the multitudinous neotropical invertebrate fauna. Dr. Beier deals with a rich collection of pseudoscorpions from isolated regions of the Andes, especially Peru. This region appears to be the developmental centre of genera like Stenolpium and Parawithius, while in Chile the nearctic genera like Dinocheirus fade out. There are many endemic species here, and Dr. Beier has found it necessary to make several new genera, all of which appear to be soundly based. Whether the Pseudoscorpions show replacement of species by altitude is difficult to determine : this is shown by such animals as some of the Chilopods, but unfortunately few of Beier's specimens have altitude data with them. The new genus Teratolpium is found at high altitudes only, but conversely Pachyolpium granulatum Beier is found from 700 to 1,630 metres. It is to be wished that, where a choice was available, the type specimen chosen should have been one from a known altitude (cf. Progarypus peruanus Beier). Problems for future investigation may be glimpsed here and there; for example, Lamprochernes, a genus of world-wide distribution, has a species high up in the Andes, while Apolpium vastum Beier has been found only on orchids. Bücherl's very important revision of the Scolopendromorph genus of Centipedes, Newportia, places the systematics of this group on a satisfactory basis for the first time. The three subgenera Newportides, Scolopendrides and Newportia had been used or not by previous authors almost according to taste or fancy. Bücherl shows quite conclusively that they apply to well-marked groups of distinct geographical range. A really workable key covers all the known species and sub-species and entails several changes of attribution and status.

F. A. TURK

\section{Crushing and Grinding}

A Bibliography. Pp. ix +425 . (London: H.M. Stationery Office, 1958. Published for the Department of Scientific and Industrial Research.) $35 s$. net.

HIS bibliography will be invaluable to the very many industrial users of the processes of crushing and grinding and to research workers interested in comminution, particle size determination and particle classification. The bibliography proper is preceded by short authoritative reviews on: fundamental aspects of crushing and grinding; problems of breakage and structure of coal ; methods of particle size analysis; industrial grinding; crushing and grinding in the ceramic industry; grinding in the cement industry ; crushing and grinding of minerals ; grinding in the field of dyestuffs and organic chemi- cals; fire and explosion hazards in crushing and grinding operations. The sections into which the bibliography itself is divided (with the number of references in each section shown in brackets) are : fundamental aspects (450); crushing and grinding practice $(354)$; coarse reduction (154) ; fine reduction (579) ; non-mechanical methods (63) ; materials (744); methods of particle size and surface area determinations (186) ; classification (160) ; dust and fire hazards (141). Nearly every reference is accompanied by a useful abstract. There is a name index and a comprehensive subject index. The Department of Scientific and Industrial Research and the small committee, under the chairmanship of Mr. A. S. White, appointed to advise on the planning of the work, together with Mr. W. H. Bickle, who undertook most of the detail of the work, are to be congratulated on this compilation. This is the second bibliography published by the Department of Scientific and Industrial Research on unit operations--the first was on industrial drying (1951); it is to be hoped that further similar bibliographies will be produced.

S. G. WARD

\section{River Pollution}

1: Chemical Analysis. By Dr. Louis Klein. Pp. ix +206 . (London: Butterworths Scientific Publications; New York: Academic Press, Inc., 1959.) $30 s . ; 3.50$ dollars.

7 HIS book is an expansion and revision of two chapters which appeared in an earlier work concerned with the general aspects of river pollution. The pollution of the rivers of Britain has been widely discussed during recent years both in lay and scientific circles. While it may well be true that "one photograph, particularly if it is in colour, may be worth a hundred dissolved oxygen samples in so far as securing public support or influencing a jury is concerned", the satisfactory resolution of the many problems involved can only be achieved after recourse to analytical methods.

Dr. Klein deals in this text with physical and chemical methods for the analysis of waters, sewage and trade wastes; biochemical methods are not considered. The recent recommendations of the official "Methods of Chemical Analysis as applied to Sewage and Sewage Effluents" and the "Recommended Methods for the Analysis of Trade Effluents" prepared by the Joint Committee of the Association of British Chemical Manufacturers and the Society of Analytical Chemistry are incorporated. No attempt is made to give detailed procedures but the many methods available are discussed critically and the most suitable method for a particular problem is indicated. The bibliography contains nearly 600 references to the literature. The appendix includes tables of saturation values for dissolved oxygen, conversion tables for various units of measurement, including degrees of hardness, tables of alkali conversion factors and various volumetric factors, and some typical analyses of waters and effluents.

There seem to be few errors; one, common to many text-books, is that ferroin can be used as indicator in the dichromate-ferrous titration. Unless an unusually high acid concentration is used the end. point is poor. The book would be of greater practical importance had experimental detail been given for the more widely applied methods. However, it should certainly prove a valuable guide to the literature of this important field. R. BELcher 